\title{
Analysis of the current state and features of natural resource potential management
}

\author{
Anna Ermakova ${ }^{1, *}$, Ludmila Oznobihina ${ }^{1}$, and Tatiana Avilova ${ }^{1}$ \\ ${ }^{1}$ Tyumen industrial University, Lunacharskogo Street, Building 2, Room 104, 625000, Tyumen, \\ Russia
}

\begin{abstract}
The article is devoted to the analysis of the current state of nature management in Mongolia. The natural resource potential of Mongolia, which includes mineral, land, water, biological and recreational resources, is shown. Administrative and legal mechanisms for managing natural resources in Mongolia and Russia are analyzed. Similar management methods of the two countries and distinctive aspects are revealed. For a more detailed consideration of the nature management features of Mongolia, the SWOT analysis method was used to identify strengths, weaknesses, opportunities and threats. Establishing chains of links between them can be useful in the future for formulating a country's strategy for the use of natural resources.
\end{abstract}

\section{Introduction}

One of the key provisions of the sustainable development of society is the replacement of the consumer economy with a moral economy. In particular, today's current economic system is a structure in which $20 \%$ of the World's population uses $80 \%$ of its resources. In this regard, according to foreign researchers, it is necessary to introduce the concept of "critical natural capital", which is understood as natural capital, which in the process of exploitation by man and his own evolution cannot be replaced by produced or cultivated and is subject to preservation. These are, first of all, some types of natural resources that perform essential ecological functions for which there are no substitutes; elements of ecosystems that are involved in life support and biodiversity; natural assets that are important for human health, aesthetic and testamentary value; cultural and natural heritage. Natural resources in a broad sense can be understood as resources that serve as the starting material for the existence, functioning and development of society, but are produced, created and formed in the natural environment, being its components [1].

Modern approaches shift the focus of the economy away from the primacy of resource productivity, thereby improving the standard of living of the world's poor and reducing the impact on the environment. This, in fact, is the basis of the principles of sustainability $[2,3]$.

At the same time, one of the main goals in the economies of different countries has been and remains the growth of industry. At the same time, the reserves of natural resources

\footnotetext{
* Corresponding author: ermakovaam@tyuiu.ru
} 
available to man are constantly decreasing, and the need to develop new ways to involve hard-to-reach resources in production is intensifying.

In this context, effective management of natural resources is essential, since funds allocated for environmental purposes are reluctant and always extremely limited, and the ability of the environment to supply industry with the necessary resources [4].

In many parts of Mongolia there is a crisis situation: not only the economic system is destroyed, but also the conditions for its functioning are practically exhausted. The only way of social and economic prosperity is the development of farms in these regions on the basis of rational use of local resources while ensuring environmental safety of the population.

Thus, the relevance of the topic is, first, that the main factor of economic growth in many countries of the world is their natural resource, and secondly, the need for rational management and use of natural resources for sustainable development through various management mechanisms.

The object of the study is the legal framework of Mongolia and Russia in the field of environmental management.

\section{Materials and methods}

Mongolia's natural resource potential includes mineral, land, water, biological (plant and animal resources) and recreational resources. Mongolia is one of the most resource-rich countries in the world, and at the same time sparsely populated. Natural resources are the basis of the country's economy [4,5].

Land resources. Mongolia's land resources cover $0.31 \%$ of the world's resources, $1.05 \%$ of the land area and $1.17 \%$ of the world's land surface. Agricultural lands of Mongolia from those in the world make up $2.54 \%$, and the land supply per inhabitant of the country as of January 12012 is 55.3 hectares (in 1919 - 242 hectares; in 1970 - 125 hectares; in 1979 - 98 hectares, in 2005 - 61.0 hectares).

The total land area of Mongolia is 156411.6 thousand hectares and its structure is presented in Fig. 1. 


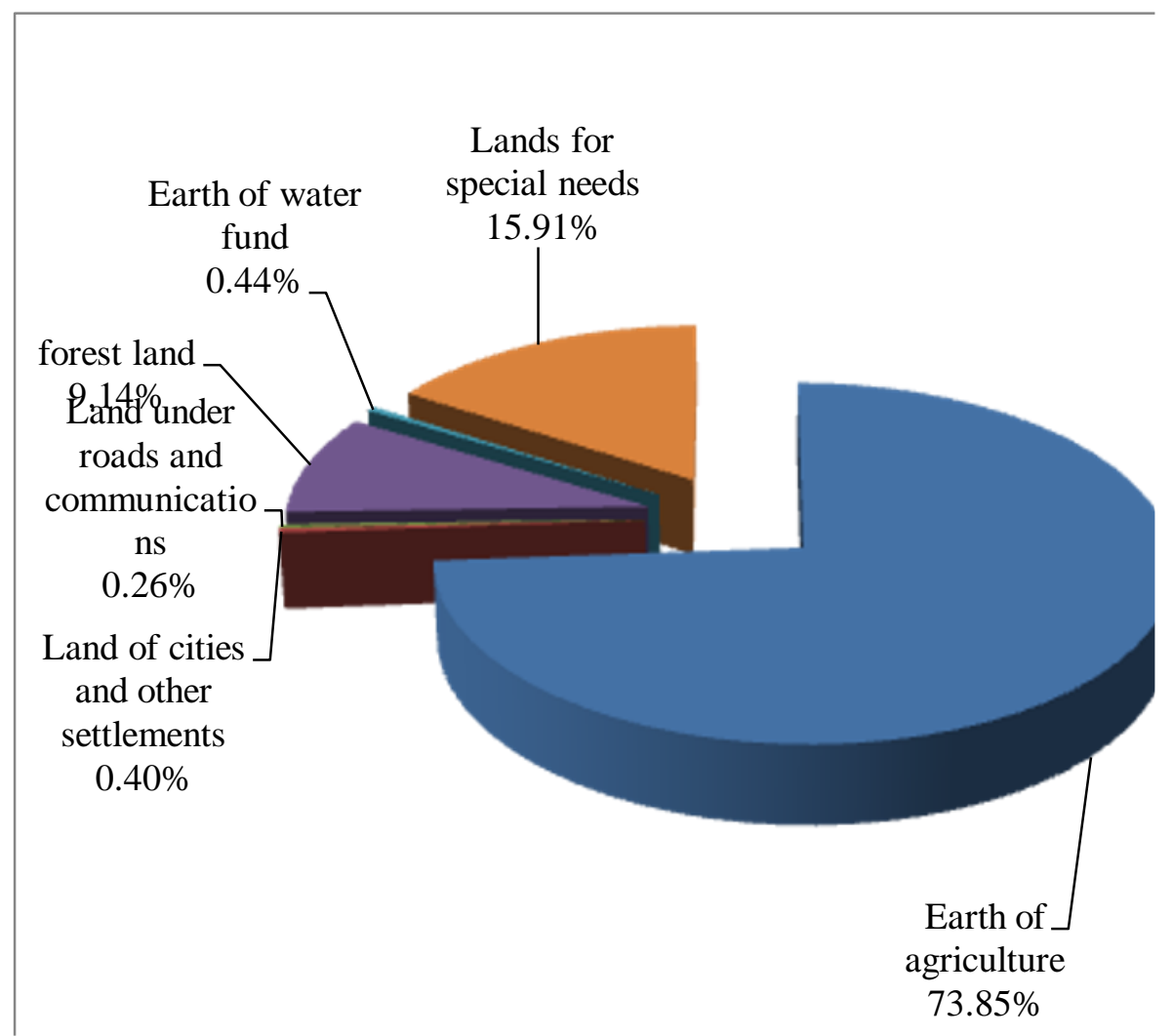

Fig. 1. The structure of the land Fund of Mongolia.

The largest areas are occupied by agricultural land $(73.86 \%)$ and land for special needs (15.91\%). Most of the agricultural land belongs to pasture lands $(96 \%)$ and about $85 \%$ of the land for special needs belongs to the lands of specially protected natural areas.

Mineral resource. Mongolia is rich in minerals, its territory revealed more than 8 thousand manifestations and about 800 deposits of 80 types of minerals.

In 2018 , mining accounted for $21.8 \%$ of GDP, $70.6 \%$ of gross industrial output and $87.7 \%$ of the country's exports, take a closer look at Fig. 2.

An important role among the natural resources of Mongolia are playing, fluorite, coal, copper-molybdenum and tin-tungsten ore, phosphate rock and etc. some Identified as aluminum-containing rocks and ores, non-ferrous and precious stones, oil and oil shale, nonmetallic building materials, various mineral water, etc. (Table 1). 




Fig. 2. Share of mining products of Mongolia.

Table 1. Proven mineral reserves of Mongolia.

\begin{tabular}{|c|c|c|}
\hline Kind of mineral & $\begin{array}{c}\text { Unit of measurement } \\
\text { (metal) }\end{array}$ & Total stock \\
\hline & Deposits of metallic minerals \\
\hline Gold /alluvial/ & tons & 218.42 \\
\hline Gold /indigenous/ & tons & 2118.44 \\
\hline Silver & thousand tons & 231.87 \\
\hline Copper & million tons & 82.74 \\
\hline Molybdenum & thousand tons & 874.1 \\
\hline Zinc & thousand tons & 3917.25 \\
\hline Iron & million tons & 253.49 \\
\hline Tungsten & thousand tons & 286.6 \\
\hline Tin & thousand tons & 55.2 \\
\hline Lead & million tons & 2.14 \\
\hline Cadmium & thousand tons & 5.8 \\
\hline Misyak & thousand tons & 25.13 \\
\hline Rhenium & tons & 9.8 \\
\hline Antimony & thousand tons & 74.52 \\
\hline Uranium & thousand tons & 90.03 \\
\hline Bismuth & thousand tons & 17.06 \\
\hline Rare earth metal & thousand tons & 1459.01 \\
\hline \multicolumn{2}{|c|}{ Coal deposits } \\
\hline
\end{tabular}




\begin{tabular}{|c|c|c|} 
Brown coal & million tons & 8136.2 \\
\hline Coal & million tons & 3269.75 \\
\hline
\end{tabular}

To date, about 600 of the 800 deposits have been explored and their reserves have been established. Now they produce in 300 deposits, 24 of them - deposits of non-ferrous metals, 181-gold, 34-coal, 15-salts and 50 deposits of common minerals.

Mongolia has large coal reserves (about 27 billion tons). Coal is common in Western and southern Mongolia, brown-in Central and Eastern Mongolia.

Gold ore. Represented by indigenous and alluvial deposits. Primary deposits (Paleozoic and Mesozoic) is usually vein type, less - mineralized zones known in the borough Johnmadsen (borough, Narinaga, Sudipta) and Bayan-Chongarskom (Tsagan-Tsahir-Ula) regions.

Significant reserves of copper ores are concentrated in two complex coppermolybdenum deposits - Erdenetiin-About (Erdenetiin-About) and Cihansumul related to stockwork porphyry copper-gold type. The deposits are located within the Selenga and South Gobi volcanic plutonic belts.

The main part of molybdenum ore reserves is concentrated in complex coppermolybdenum, stockwork and greisen molybdenum-tungsten deposits and a small part-in the actual molybdenum Deposit of stockwork type Aryn-Nur in the East of the country.

Deposits of actual silver ores were found in the Mongolian Altai (Askhat, Tolbo-Nur, etc.). As a passing component, silver is found in polymetallic and porphyry copper deposits.

In addition, South Mongolia, opened a new zone of magmatic rocks of elevated alkalinity, including identified ore nodes and areas prospective for rare earth elements (Login - Gol, Han-Bogdo, Mushugai-Khuduk, etc.). In Mongolia, large reserves of formation phosphorites in the Khubsugul phosphorite-bearing basin located in the North of the country have been identified and preliminarily evaluated. The geosynclinal phosphorites ("Karatau") type; age - lower Cambrian; major deposits (Hovsgol, South Bhagol, Bürenhaan, Mangan-Ula) located on the Western shore of lake Hovsgol and to the South. The average content of $\mathrm{P} 2 \mathrm{O} 5$ in the ore is about 20\%; reserves are estimated at the first billion tons.

The largest explored reserves deposits of Mongolia include:

- «Tavantolgoi»-coal - 7 trillion tons;

- «Oyutolgoi» - copper - 24 million tons;

- «Tsagan suvarga» - copper - 1.3 million tons, molybdenum - 48.2 thousand tons;

- «Mardi» - Uranium - 924.6 thousand tons;

- «Tumurtei»-iron ore - 229.3 million tonnes;

- «Bayangol» - iron ore - 210 thousand tons;

- «Bartelt» - iron ore - 31 million tonnes;

- «Bartelt»- iron ore - 31 million tonnes;

- «Hust Ul» - iron ore 4.4 million tons;

- «Ulan»- lead-186.4 thousand tons, zinc-245.8 thousand tons;

- «TSAV» - lead - 226.2 thousand tons, zinc - 23.3 thousand tons;

- «Boro» - gold ore -3.4 million tons.

Forest resources. The forest Fund of Mongolia includes coniferous and deciduous forests located in the North of the country between the Siberian taiga and the Central Asian desert, they are characterized by limited natural regeneration and a tendency to fires, and saxaul forests, common in the Gobi deserts in the South of the country.

Area of forest Fund lands was 14297.9 thousand hectares, which is of $9.14 \%$ of the total territory of the country $(75.1 \%$ in coniferous and deciduous forests, 24.9 per cent of saxaul forest). The level of forest cover in Mongolia is $8.26 \%$, let us take a closer look at Fig. 3. 
Total timber reserves of Mongolia reaches 1313 million, $4 \mathrm{~m}^{3}$, of which are located in the North -1311.9 million $\mathrm{m}^{3}(99.9 \%)$, and in the South -1527.1 thousand $\mathrm{m}^{3}(0.1 \%)$. Stocks of wood on a root on one inhabitant of the country account for $371 \mathrm{~m}^{3}$. The average annual growth of forests is 10.5 million $\mathrm{m}^{3}$ and the average stock per 1 ha is $107.5 \mathrm{~m}^{3}$.

In addition, the forest Fund of Mongolia consists of protective and operational forests. Protective forests cover $82.9 \%$ of the total forest area, while operational forests cover $17.1 \%$. The volume of wood reserves of protective forests is 1002 million $\mathrm{m}^{3}[5,6]$.

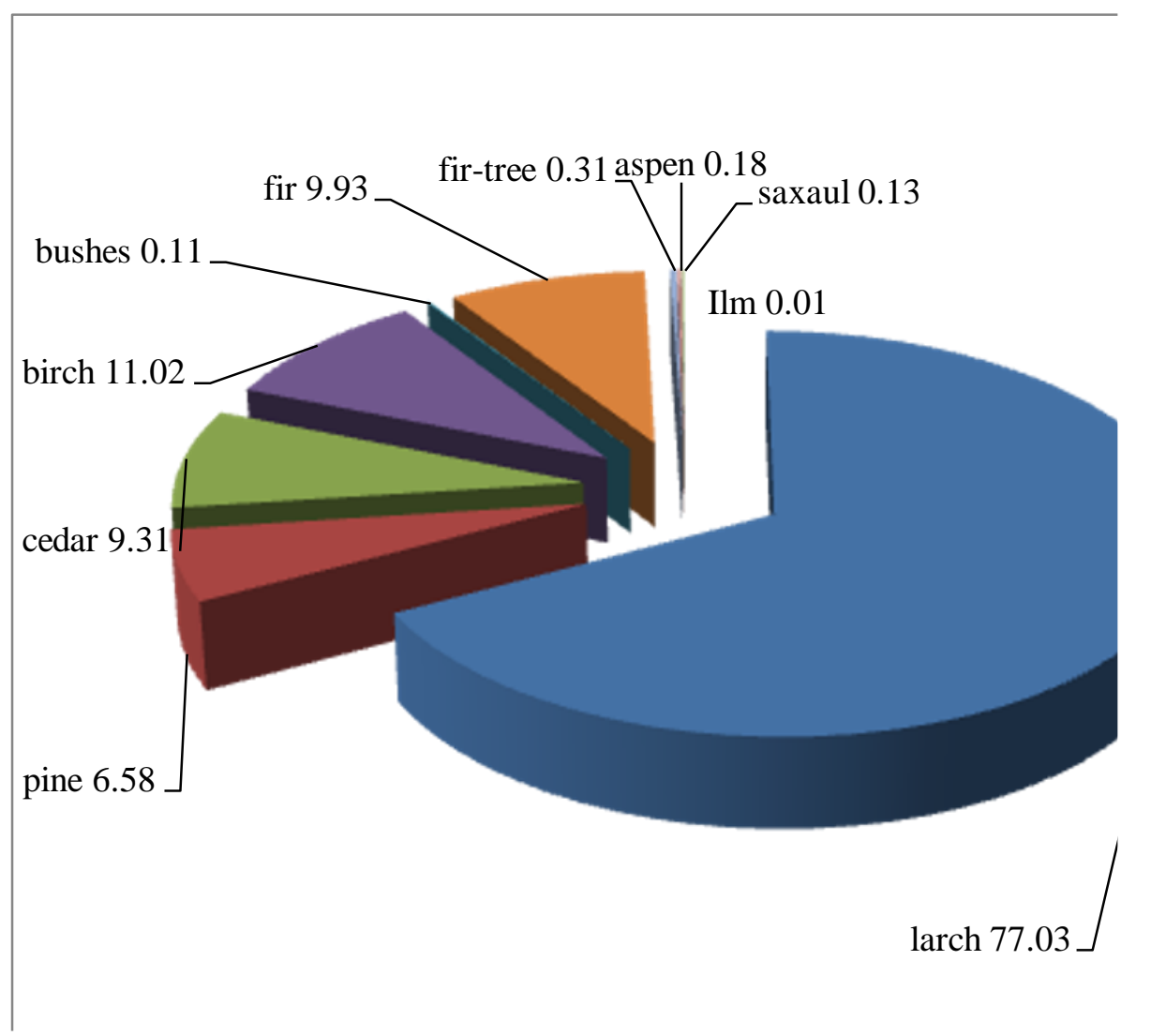

Fig. 3. Wood reserves by species group as a percentage of total reserves.

Water resources management. Mongolia has significant reserves of surface and groundwater. Water reserves in Mongolia are presented in Table 2.

Table 2. Water reserves in Mongolia, $\mathrm{km}^{3}$.

\begin{tabular}{|c|c|c|c|c|}
\hline \multirow{2}{*}{ Name of aimags } & \multicolumn{2}{|c|}{ Superficial water } & \multicolumn{2}{c|}{ Subterranean water } \\
\cline { 2 - 5 } & $\begin{array}{c}\text { In all, in } \\
\text { the sum }\end{array}$ & $\begin{array}{c}\text { The allowable } \\
\text { amount of } \\
\text { consumption }\end{array}$ & Ground & $\begin{array}{c}\text { The allowable } \\
\text { amount of } \\
\text { consumption }\end{array}$ \\
\hline Handiski & 6.69 & 0.4 & 2.7 & 0.8 \\
\hline Jushunsky & 6.59 & 0.16 & 2.49 & 1.95 \\
\hline Sachanski & 3.16 & 0.2 & 1.14 & 0.37 \\
\hline
\end{tabular}




\begin{tabular}{|c|c|c|c|c|}
\hline Arkhangai & 2.83 & 0.2 & 1.06 & 0.063 \\
\hline Bayan & 2.39 & 0.29 & 1.05 & 0.52 \\
\hline Selenge & 3.2 & 1.77 & 0.97 & 0.39 \\
\hline Central & 1.91 & 0.2 & 0.59 & 0.2 \\
\hline Bulgan & 1.75 & 0.94 & 0.5 & 0.15 \\
\hline Eastern & 1.51 & 0.15 & 0.3 & 0.2 \\
\hline Ulaan-Baatar & 0.77 & 0.05 & 0.3 & 0.1 \\
\hline Kordoski & 1.1 & 0.19 & 0.25 & 0.06 \\
\hline UVS-Nurskaya & 1.2 & 0.12 & 0.23 & 0.08 \\
\hline Uvurhangai & 0.56 & 0.22 & 0.1 & 0.05 \\
\hline Bayanhongor & 0.45 & 0.05 & 0.1 & 0.05 \\
\hline Gobi-Altay & 0.058 & 0.01 & 0.1 & 0.03 \\
\hline Vostochnosibirskaya & 0.05 & - & 0.1 & 0.005 \\
\hline Srednekolymskiy & 0.12 & - & 0.08 & 0.01 \\
\hline Sukhe-Bator & 0.14 & - & 0.03 & 0.01 \\
\hline Darkhan-Ulski & 0.044 & 0.01 & 0.01 & 0.003 \\
\hline South & 0.038 & - & 0.01 & 0.001 \\
\hline Gobi-Sumber & 0.01 & - & 0.001 & 0.0001 \\
\hline Orkhon & 0.005 & 0.001 & 0.001 & 0.0001 \\
\hline In all, in the sum & 34.6 & 4.96 & 12 & 5.6 \\
\hline
\end{tabular}

These tables allow us to judge that the groundwater reserve in the city of Ulaanbaatar is $0.3 \mathrm{~km} 3$, and according to this indicator, the city of Ulaanbaatar ranks tenth among the 21 aimags in the country. Considering that Ulaan-Baatar is home to almost 40 per cent of the population (1240 thousand persons) and account for only $2.5 \%(0.3 \mathrm{~km} 3)$ of groundwater and $2.2 \%$ (to $0.77 \mathrm{~km} 3$ ) of surface water supplies, these numbers are very small, especially when compared with sparsely populated aimags as Antiskin (65.8 thousand persons), Holthuijsen (USD 114.9 thousand people) and Sachanski (65.5 thousand people).

In Mongolia, according to preliminary data of the state accounting of waters 2011, there were 6646 rivers, lakes 3613, 10557 springs, 265 sources of mineral water, 225 icy river.

Inventory of water per $1 \mathrm{~km} 2$ area ledaroot Jushunsky, Handiski Bayan-Ulgiyski aimag and water supplies for 1 person - Selenga, Jushunsky Bayan-Ulgiisky and Arkhangai aimags.

\section{Results}

Thus, the characteristics of Mongolia's natural resources are as follows:

- $\quad$ the third part of the land Fund of the country is agricultural land, 96\% of which is occupied by pasture land;

- $\quad$ small deposits are distributed almost throughout the country, and large deposits (eg., deposits of coal, copper and phosphorus) are located in the North, East and South-East;

- forest and water resources are concentrated in the North of the country and occupy small areas, while their areas and reserves are depleted due to irrational use and imperfect protection system. 
At present, the development of administrative and legal means of natural resources management is given considerable attention in legislation and practice. The instruments of the administrative machinery are closely interrelated with the regulatory and legal regulation of environmental management [7].

The administrative mechanism contains functional and situational methods of governance on the part of the authorities, and the legal mechanism of governance forms the main legal institutions, including sources of natural resource law; Legal liability for environmental offences; Compensation for harm caused by the use or depletion of natural resources. The peculiarities of natural resource management of Mongolia and Russia are presented in the following compared Table 3.

Table 3. Elements and their examples of legal and administrative mechanisms for natural resources management in Russia and Mongolia.

\begin{tabular}{|c|c|c|c|}
\hline \multicolumn{2}{|c|}{$\begin{array}{l}\text { Mechanisms for natural resource } \\
\text { management in Russia }\end{array}$} & \multicolumn{2}{|c|}{$\begin{array}{l}\text { Natural resource management mechanisms in } \\
\text { Mongolia }\end{array}$} \\
\hline $\begin{array}{l}\text { Elements } \\
\text { of } \\
\text { mechanis } \\
\text { ms }\end{array}$ & $\begin{array}{l}\text { Examples of the use of natural } \\
\text { resource management } \\
\text { mechanisms in the Russian } \\
\text { Federation } \\
\end{array}$ & $\begin{array}{l}\text { Elements of } \\
\text { mechanisms }\end{array}$ & $\begin{array}{l}\text { Examples of natural resource } \\
\text { management mechanisms in } \\
\text { Mongolia }\end{array}$ \\
\hline \multicolumn{4}{|c|}{ legal mechanism } \\
\hline $\begin{array}{l}\text { Internati } \\
\text { onal } \\
\text { standard } \\
\text { acts }\end{array}$ & $\begin{array}{l}\text { - Convention on International } \\
\text { Trade in Endangered Species of } \\
\text { Wild Fauna and Flora (SITES); } \\
\text { - Pan-European Biological and } \\
\text { Landscape Diversity Strategy. }\end{array}$ & $\begin{array}{l}\text { International } \\
\text { standard acts }\end{array}$ & $\begin{array}{c}\text { - Convention on International } \\
\text { Trade in Endangered Species of } \\
\text { Wild Fauna and Flora (SITES); } \\
\text { - United Nations Convention to } \\
\text { Combat Desertification in Those } \\
\text { Countries Experiencing Serious } \\
\text { Drought and/or Desertification, } \\
\text { Particularly in Africa. }\end{array}$ \\
\hline $\begin{array}{l}\text { Constitut } \\
\text { ion of } \\
\text { the } \\
\text { Russian } \\
\text { Federatio } \\
\text { n }\end{array}$ & $\begin{array}{c}\text { Article 9. - Land and other } \\
\text { natural resources are used and } \\
\text { protected in the Russian } \\
\text { Federation as the basis for the } \\
\text { life and activities of the peoples } \\
\text { living in the territory concerned. } \\
\text { Land and other natural resources } \\
\text { may be in private, public, } \\
\text { municipal and other forms of } \\
\text { ownership. }\end{array}$ & $\begin{array}{l}\text { Constitution } \\
\text { of Mongolia }\end{array}$ & $\begin{array}{l}\text { Article } 6 . \text { - State ownership is } \\
\text { the earth (except the lands } \\
\text { provided to citizens in property) } \\
\text { and its subsoil, resources of a } \\
\text { subsoil, the woods, water } \\
\text { resources and animals. Land } \\
\text { may be provided in the property } \\
\text { of citizens other than pasture } \\
\text { land, public land and land for } \\
\text { public special needs. }\end{array}$ \\
\hline $\begin{array}{l}\text { Federal } \\
\text { laws }\end{array}$ & $\begin{array}{l}\text { Land, Water, Forest Codes, } \\
\text { Federal Law "On Subsoil," etc. } \\
\text { - Federal property. }\end{array}$ & Federal laws & $\begin{array}{c}\text { Land Law, Water Law, Forest } \\
\text { Law, Mineral Law and other } \\
\text { laws, } \\
\text { - Public and private property. }\end{array}$ \\
\hline
\end{tabular}




\begin{tabular}{|c|c|c|c|}
\hline $\begin{array}{c}\text { Federal } \\
\text { laws }\end{array}$ & $\begin{array}{l}\text { - Ownership of the constituent } \\
\text { entities of the Russian } \\
\text { Federation, municipal and } \\
\text { private ownership of land; } \\
\text { - State property - forest fund, } \\
\text { there are reserve forests; } \\
\text { - Land and other natural } \\
\text { resources - real estate; } \\
\text { - License for geological study } \\
\text { and mining, agreements on } \\
\text { product division (at least } 80 \% \text { - } \\
\text { employees - citizens of the } \\
\text { Russian Federation), joint } \\
\text { license } \\
\text { - Conclusion of a water use } \\
\text { contract for a new period of } \\
\text { time. }\end{array}$ & Federal laws & $\begin{array}{l}\text { Land ownership (Mongolia } \\
\text { citizens only); } \\
\text { - Foreign natural and legal } \\
\text { persons, stateless persons - users } \\
\text { of land; } \\
\text { - Land and other natural } \\
\text { resources are not considered real } \\
\text { estate; } \\
\text { - Special permit for exploration } \\
\text { and extraction of minerals, } \\
\text { agreements on division of } \\
\text { products (not less than 90\% of } \\
\text { workers-citizens of Mongolia) } \\
\text { Extension of the water use } \\
\text { contract to } 5 \text { years. }\end{array}$ \\
\hline \multicolumn{4}{|c|}{ Administrative mechanism } \\
\hline $\begin{array}{c}\text { Direct } \\
\text { bans }\end{array}$ & $\begin{array}{l}\text { Federal Law "On Environmental } \\
\text { Protection" } \\
\text { Article 51. It is prohibited to } \\
\text { dump production and } \\
\text { consumption wastes, including } \\
\text { radioactive wastes, into surface } \\
\text { and underground water bodies, } \\
\text { on catchment areas, in the } \\
\text { subsoil and on the soil. } \\
\text { Federal Law "On Specially } \\
\text { Protected Natural Areas." } \\
\text { Article } 7 \text {. Within the boundaries } \\
\text { of State nature reserves, any } \\
\text { activity contrary to the } \\
\text { objectives of State nature } \\
\text { reserves is prohibited. }\end{array}$ & Direct bans & $\begin{array}{l}\text { Environmental Protection Act } \\
\text { Article } 21 \text { Citizens and legal } \\
\text { entities undertake not to pollute } \\
\text { the environment with industrial } \\
\text { and domestic waste. } \\
\text { - Law "On specially protected } \\
\text { areas." } \\
\text { Article 9. Any activity is } \\
\text { prohibited in the protected area, } \\
\text { except } \\
\text { Observation and research } \\
\text { activities that do not cause } \\
\text { damage to the natural } \\
\text { environment. }\end{array}$ \\
\hline
\end{tabular}




\begin{tabular}{|c|c|c|c|}
\hline $\begin{array}{l}\text { Environ } \\
\text { mental } \\
\text { certificat } \\
\text { ion }\end{array}$ & $\begin{array}{c}\text { Order MPR Russian Federation } \\
\text { of } 28.12 .2000 \text { No. } 609 \text { "About } \\
\text { enforcement of the System of } \\
\text { certification of objects of } \\
\text { resource use in the Russian } \\
\text { Federation"; } \\
\text { - Environmental certificates: } \\
\text { ISO 9000, ISO 14000, ISO } \\
14001 \text {; } \\
\text { - GOST 40000, GOST R ISO } \\
\text { 9000, GOST R ISO 14000. } \\
\text { - GOST R 51232-98. } \\
\text { Drinking water. General } \\
\text { requirements for organization } \\
\text { and methods of quality control. }\end{array}$ & $\begin{array}{c}\text { Environment } \\
\text { al } \\
\text { certification }\end{array}$ & $\begin{array}{l}\text { International Certificates: ISO } \\
14001 \\
\text { - National Standard of Mongolia } \\
\text { "Drinking Water. Sanitary } \\
\text { requirements, quality, safety } \\
\text { assessment "MNS 900:2005. } \\
\text { - Waste water requirements } \\
\text { MNS 4943:2000 }\end{array}$ \\
\hline $\begin{array}{l}\text { Licensin } \\
\mathrm{g}\end{array}$ & $\begin{array}{l}\text { License for water use, subsoil } \\
\text { use, forest management, etc. } \\
\text { (Forest ticket, special permit for } \\
\text { use of water facilities); } \\
\text { - Exploration license - up to } 5 \\
\text { years; For production - up to } 20 \\
\text { years; Joint - up to } 25 \text { years. }\end{array}$ & Licensing & $\begin{array}{l}\text { Water permit, forest order, } \\
\text { special mineral permit; } \\
\text { - Special exploration permit - for } \\
3 \text { years; For production - } 30 \\
\text { years with extension for } 20 \text { years } \\
\text { or more (up to } 100 \text { years). }\end{array}$ \\
\hline $\begin{array}{l}\text { Liability } \\
\text { for } \\
\text { environ } \\
\text { mental } \\
\text { rights }\end{array}$ & $\begin{array}{l}\text { The Federal Law "On } \\
\text { Environmental Protection" } \\
\text { article } 75 \text { - For violation of } \\
\text { legislation in the field of } \\
\text { environmental protection, } \\
\text { property, disciplinary, } \\
\text { administrative and criminal } \\
\text { liability is established in } \\
\text { accordance with the legislation. }\end{array}$ & $\begin{array}{l}\text { Liability for } \\
\text { environmenta } \\
1 \text { rights }\end{array}$ & $\begin{array}{l}\text { Law "On Protection of the } \\
\text { Natural Environment" Article } 50 \\
\text { - For violation of the law in the } \\
\text { field of environmental protection } \\
\text { to guilty persons, depending on } \\
\text { the circumstances of the offence } \\
\text { and the amount of damage, } \\
\text { criminal and administrative } \\
\text { liability is established in } \\
\text { accordance with the law. }\end{array}$ \\
\hline
\end{tabular}

Thus, the administrative and legal mechanisms of natural resources management in Mongolia and Russia differ in the following aspects:

- Mongolian laws are united for all administrative-territorial units, and in Russia there are not only federal laws, but also laws of the constituent entities of the federation;

- Each individual law of Mongolia provides for liability for violations of the law, and in Russia - in addition to the existence of an article on liability for violations of the law in each law and code, there is still a Code on Administrative Offences;

- Mongolia has administrative and criminal liability for violations of legislation, and Russia has administrative, disciplinary, criminal and material liability;

- In Mongolia, environmental protection is one of the duties of citizens and legal entities, and in Russia - in addition to the duties for environmental protection, laws and 
codes specify actions prohibited in the territory of the country with regard to the environment.

\section{Discussion}

For a more detailed consideration of the features of natural resources management in Mongolia, we apply the method of SWOT analysis.

SWOT analysis is the study of strengths, weaknesses, opportunities and threats that help to clarify the circumstances in which the object of study exists. In our case, the objects of study are Mongolia.

The SWOT methodology involves first identifying strengths and weaknesses, as well as threats and opportunities, and then establishing chains of links between them, which can then be used to formulate a country's strategy for the use of natural resources.

First, a country-specific list of strengths and weaknesses, as well as a list of threats and opportunities, is compiled for each country, taking into account the specific situation in which the countries are located. List of strengths, weaknesses and threats, opportunities of Mongolia Table 4.

Table 4. SWOT analysis.

\begin{tabular}{|c|c|}
\hline $\begin{array}{c}\text { Strength } \\
\text { - Natural resource potential; } \\
\text { - Free provision of land plots to citizens in } \\
\text { ownership during the land reform; } \\
\text { - Tax privileges and privileges on payment of } \\
\text { land payments to families-cattle breeders, } \\
\text { owners of lands. }\end{array}$ & $\begin{array}{c}\text { Weakness } \\
\text { - Population size; } \\
\text { - Only Mongolian citizens have the right to own } \\
\text { land; } \\
\text { - Land and other natural resources are not } \\
\text { legally considered real estate; } \\
\text { - Lack of state planning system for subsoil } \\
\text { exploration and mining of the country; } \\
\text { - Limitation of the configuration and areas of } \\
\text { subsoil plots (rectangle - from } 25 \text { to } 400 \\
\text { hectares.) } \\
\text { - The actual lack of disciplined responsibility in } \\
\text { the management of natural resources; } \\
\text { - Low level of penalties. }\end{array}$ \\
\hline $\begin{array}{c}\text { Opportunity } \\
\text { - Support of the Government and international } \\
\text { organizations, communities for land reform and } \\
\text { other environmental programs, projects; } \\
\text { - Investment growth in the country's economic } \\
\text { sectors; } \\
\text { - Increase in the number and area of specially } \\
\text { protected natural areas; } \\
\text { - Tourism development; } \\
\text { - Development of eco-business and increase of } \\
\text { export of organic products; } \\
\text { - Processing industry of copper, coal and other } \\
\text { minerals; } \\
\text { Growth of copper; } \\
\text { - The legislation is constantly being improved. }\end{array}$ & $\begin{array}{c}\text { Threat } \\
\text { - Reduction of land reclamation quality; } \\
\text { - Illegal use of natural resources and water } \\
\text { scarcity; } \\
\text { - Desertification and degradation of pastures; } \\
\text { - Urbanization; } \\
\text { - Smog and pollution; } \\
\text { - Uncontrolled use of natural resources. }\end{array}$ \\
\hline
\end{tabular}




\section{Conclusion}

It should be noted that the problems of natural resources management that arise in Mongolia are also typical for Russia, since the legal support and management methods have a number of similar characteristics:

- natural resources management is under the authority of three ministries;

- the main economic mechanism of management is the payment for the use of natural resources;

- similar tax and penalty systems.

- At the same time, there are significant differences in the system of natural resources management in both countries:

- legal support of natural resources management in the regions of the countries;

- in the territorial management of natural resources;

- development of research works in the field of natural resources management.

Thus, in modern science and practice, the theoretical and methodological foundations of natural resource management constantly require attention aimed at improving the management system and improving the efficiency of natural resource management in both Mongolia and Russia.

\section{References}

1. I. Kustysheva, IOP Conference Series: Materials Science and Engineering, 262 (1), № 012166 (2017) DOI: 10.1088/1757-899X/262/1/012166

2. A. Kryakhtunov, O. Bogdanova , Z. Zakharov, Moscow economic magazine, 1, 11 15, 2019) DOI: 10.24411/2413-046X-2019-11011

3. A. Kryakhtunov, O. Bogdanova , E. Chernykh, IOP Conference series: materials science and engineering (2017) DOI: 10.1088/1757-899X/262/1/012188

4. A. Ermakova, Nfluence of price-forming factors on the cost of land in Yekaterinburg. Moscow economic magazine, №10, p. 49 (2019) DOI 10.24411/2413-046X-201910059

5. A. Karpik, V. Zharnikov, Bulletin of the Siberian State University of Geosystems and Technologies, 24, №3, 141 - 157 (2019) DOI: 10.33764/2411-1759-2019-24-3-141157

6. I.V. Komar, The rational use of natural resources and resource cycles (2011)

7. E.P. Romanova, L.I. Kurakova, Yu.G. Ermakov, Natural resources of the world (2012) 